DANUTA Piróg

Uniwersytet Pedagogiczny w Krakowie, Polska - Pedagogical University of Cracow, Poland

\title{
Wybrane determinanty przedsiębiorczości indywidualnej - zarys stanu badań
}

\section{Selected Determinants of Individual Entrepreneurship: an Outline of the Current State of Research}

Streszczenie: Przedsiębiorczość indywidualna jest jednym z ważniejszych czynników rozwoju społeczno-gospodarczego regionów w różnej skali układów przestrzennych oraz istotnym sposobem uelastyczniania rynku pracy. Studia specjalistycznej literatury jednoznacznie wskazują na istnienie wielu determinant wpływających na skłonność jednostki do samozatrudnienia. Są to zarówno kwestie ekonomiczne (np. poziom rozwoju gospodarczego, sytuacja na rynku pracy, polityka fiskalna), jak i pozaekonomiczne (np. płeć, wiek, wykształcenie, stan cywilny, posiadanie dzieci, wcześniejsze doświadczenie na rynku pracy). Celem autorki artykułu jest dokonanie przeglądu krajowych i zagranicznych prac teoretycznych, poświęconych determinantom przedsiębiorczości indywidualnej, a także syntezy wyników badań, weryfikujących wpływ czynników pozaekonomicznych na poziom samozatrudnienia. Przeprowadzone badania literaturowe, dotyczące roli czynników ekonomicznych w podejmowaniu samozatrudnienia wskazują, że w ujęciu międzynarodowym jego poziom pozostaje przede wszystkim w ścisłym związku z wartością PKB. W grupie czynników pozaekonomicznych dowiedziono zaś znaczącego wpływu płci, wieku, stanu cywilnego oraz poziomu wykształcenia na skłonność do rozpoczęcia działalności gospodarczej.

\begin{abstract}
Individual entrepreneurship is among the key factors of social and economic development of regions in various scales of spatial settings. It is also an important way of increasing the flexibility of the labor market. Specialist literature clearly shows that there is a multitude of determinants influencing an individual's willingness to become self-employed. They include both economic factors (e.g. the level of economic development, labor market situation, fiscal policy) and non-economic ones (e.g. the person's gender, age, education level, marital status, whether or not the person has children, the person's previous experience on the labor market). This paper serves the following purposes: a review of Polish and foreign theoretical studies on the determinants of individual entrepreneurship; a synthesis of the findings of studies verifying the impact of non-economic factors on an individual's decision to become self-employed. Literature studies on the economic factors' role on individuals' decision to become self-employed show that, internationally, the scale of self-employment is essentially in close correlation with the GDP. Among the non-economic factors, gender, age, marital status and education level have been demonstrated to significantly influence the willingness to start one's own business.
\end{abstract}


Słowa kluczowe: czynniki ekonomiczne; czynniki pozaekonomiczne; przedsiębiorczość indywidualna; samozatrudnienie

Key words: economic factors; individual entrepreneurship; non-economic factors; self-employment

Otrzymano: 6 listopada 2015

Received: 6 November 2015

Zaakceptowano: 2 marca 2016

Accepted: 2 March 2016

\section{Sugerowana cytacja/Suggested citation:}

Piróg, D. (2016). Determinanty przedsiębiorczości indywidualnej - zarys stanu badań. Przedsiębiorczość - Edukacja, 12, 300-314.

\section{Wstęp}

Przedsiębiorczość, definiowana najczęściej jako zespół cech, predyspozycje, postawy, talent, inicjatywa gospodarcza, działalność innowacyjna, ma różne oblicza. Stosując podział ze względu na formę organizacyjno-prawną oraz rodzaj inspiracji, rozumiany jako czynnik stymulujący, wyróżnia się trzy typy przedsiębiorczości: indywidualną, korporacyjną (wewnętrzną) oraz rodzinną (Koźmiński, 2004; Chodyński, 2008; Chyba, 2015). Wśród nich rolę ważnego inicjatora rozwoju gospodarczego w różnej skali układów przestrzennych przypisuje się przedsiębiorczości indywidualnej, która przez samozatrudnienie jest uznawana za istotną strategię uelastyczniania rynku pracy $^{1}$ (Lemańska-Majdzik, 2008, 2013; Czerniachowicz, 2011; Szepelska, 2013). Przedsiębiorczość indywidualna jako alternatywny sposób zatrudnienia zapobiega bowiem nasilaniu się bezrobocia. Osobom poszukującym bezskutecznie pracy najemnej pozwala na powrót do grona pracujących. Ci przedsiębiorcy, którzy wykreowali miejsca pracy (ang. swichers), zwiększają popyt na pracę (Kaczorowski, 2011; Tyrowicz, 2011).

Z ekonomicznego punktu widzenia przejście do samozatrudnienia powinno następować wówczas, kiedy korzyści płynące z tej formy pracy przewyższają profity materialne i pozamaterialne z bycia zatrudnionym (Douglas, Shepherd, 2002). Studia literatury uprawniają do stwierdzenia, że występuje szereg innych czynników warunkujących skłonność jednostki do samozatrudnienia (m.in. Dawson i in., 2009; Livanos, 2009; Kraska, 2010; Czerniachowicz, 2011; Korpysa, 2011; Lechmann, Schnabel, 2011; Tyrowicz, 2011; Gindling, Newhouse, 2013; Kopycińska, 2013; Kunasz, 2013, 2014; Piróg, 2014; Simoes i in., 2013). Dla części ludzi decyzja o samozatrudnieniu jest efektem ich przedsiębiorczej postawy, potrzeby niezależności, chęci zdobycia wyższego statusu społecznego, zrealizowania swoich celów, ambicji zawodowych. Dla innych to jedyna alternatywa wobec bezrobocia. Dla jeszcze innych pracę na własny rachunek warunkuje konieczność wynikająca z sytuacji życiowej bycia aktywnym zawodowo tylko w elastycznym czasie pracy, jakiego nie mogli wynegocjować u pracodawców. W krajach rozwijających się samozatrudnienie może być postrzegane jako oblicze nieformalnego zatrudnienia (Dawson i in., 2009).

Ze względu na złożoność oraz wielowymiarowość samej przedsiębiorczości, a także determinant wpływających na skłonność jednostki do samozatrudnienia powinna być ona

\footnotetext{
${ }^{1}$ Samozatrudnienie jest tłumaczeniem angielskiego sformułowania self-employment. Określa się je także jako pracę na własny rachunek, działalność gospodarczą osób fizycznych czy indywidualną działalność gospodarczą.
} 
rozpatrywana zarówno pod względem ekonomicznym, jak i społeczno-kulturowym (Lemańska-Majdzik, 2008). Założenie to jest realizowane w pracach teoretycznych i empirycznych poświęconych tej problematyce, w których najczęściej wyodrębniane są tzw. ekonomiczne i pozaekonomiczne determinanty przedsiębiorczości indywidualnej.

Do czynników ekonomicznych zaliczane są: sytuacja na rynku pracy, poziom rozwoju gospodarczego, polityka fiskalna, polityka monetarna, oczekiwane różnice w dochodach, mobilność siły roboczej, posiadane lub dostępne środki finansowe.

Zaś jako determinanty pozaekonomiczne wskazuje się: kapitał ludzki, a w nim płeć, wiek, stan zdrowia, wykształcenie, stan cywilny, posiadanie dzieci, cechy osobowości (zdolności przedsiębiorcze, skłonność do ryzyka), czynniki geograficzno-lokalizacyjne i narodowość, wpływ innych osób, zwłaszcza członków rodziny (Kopycińska, 2013; Kunasz, 2013, 2014; Simoes i in., 2013, van der Zwan i in., 2013).

W literaturze stosowane jest także podejście do czynników wpływających na samozatrudnienie rozpatrywanych z punktu widzenia modelów przedsiębiorczości. Wówczas - przy założeniu, że w każdym człowieku istnieje pierwiastek przedsiębiorczości - wyróżnia się działanie czynników mikropodażowych oraz makro- i mezopopytowych (Korpysa, 2011).

Celem autorki niniejszego artykułu jest dokonanie, przy zastosowaniu metody studiów literatury:

- przeglądu krajowych i zagranicznych prac teoretycznych, poświęconych determinantom przedsiębiorczości indywidualnej,

- syntezy wyników badań empirycznych, weryfikujących wpływ czynników pozaekonomicznych na poziom samozatrudnienia.

\section{Determinanty ekonomiczne}

Do wiodących ekonomicznych czynników przedsiębiorczości indywidualnej zalicza się sytuację gospodarczą i bezpośrednio z nią związane realia rynku pracy. Zachowania jednostki w obliczu zmian koniunktury gospodarczej, w tym jej stopnień aktywnego zainteresowania się samozatrudnieniem, zostały przedstawione w teorii push i pull. Teorię push oparto na założeniu, że stabilny i bezpieczny rynek pracy nie jest dobrym impulsem do otwierania działalności gospodarczej. Zgodnie z tą teorią wysoka stopa bezrobocia na rynku pracy pozytywnie wpływa na poziom samozatrudnienia, ponieważ prowokuje tzw. efekt uchodźstwa. Ludzie, chcąc mieć źródło dochodu, decydują się na rozpoczęcie własnej działalności gospodarczej, uznając, że jest to dla nich jedyna alternatywa uratowania się przed problemem bezrobocia. Wzrost liczby takich osób statystycznie zwiększa szanse na powodzenie, co w efekcie redukuje skalę bezrobocia w ogóle. Trudności na rynku pracy mogą pobudzać do samozatrudnienia wszystkie osoby, bez względu na poziom wykształcenia (Piróg, 2014). Badania wskazują, że taka sytuacja wpłynęła na podjęcie decyzji o samozatrudnieniu przez $42 \%$ osób pracujących na własny rachunek w Polsce, podczas gdy np. w Norwegii była ona bodźcem do takich działań dla 5\% przedsiębiorców (Kaczorowski, 2011). Zaś teoria prosperity pull wychodzi z odmiennego założenia, że jedynie stabilny i bezpieczny rynek pracy z niskim poziomem bezrobocia ośmiela do podejmowania prób samozatrudnienia (Piróg, 2014).

Ilustracją tych teorii są zachowania ludzi funkcjonujących na rynku pracy w gospodarkach o różnym poziomie rozwoju. Jak wskazują dane, trendy w samozatrudnieniu oraz poziom samozatrudnienia w ujęciu międzynarodowym są względnie stałe i pozostają w ścisłym w związku 
z PKB. W krajach o wyższym poziomie PKB odsetek samozatrudnionych jest niższy niż w krajach rozwijających się. Dowodem na występowanie takiej tendencji są dane zawarte w tabeli 1. Większość pracowników w krajach rozwijających się to samozatrudnieni (53,2\%), a tylko jedna czwarta to pracownicy najemni. Kraje o średnim dochodzie narodowym brutto notują blisko jedną trzecią samozatrudnionych, natomiast kraje o wysokim dochodzie charakteryzują się odsetkiem samozatrudnionych na poziomie 13,0\% (w tym 9,3\% to samozatrudnieni, a 3,7\% pracodawcy), a odsetek pracowników najemnych w tych krajach utrzymuje się na poziomie aż 85,9\% (Gindling, Newhouse, 2013).

Tab. 1. Struktura pracujących (\%) w krajach o różnym poziomie dochodu narodowego brutto

\begin{tabular}{|l|c|c|c|c|}
\hline \multicolumn{1}{|c|}{ DNB $^{*}$} & $\begin{array}{c}\text { Zatrudnieni } \\
\text { (z wynagrodzeniem) }\end{array}$ & $\begin{array}{c}\text { Zatrudnieni (bez } \\
\text { wynagrodzenia) }\end{array}$ & Pracodawca & Samozatrudniony \\
\hline niski & 25,2 & 21,6 & 1,6 & 51,6 \\
\hline średni & 46,0 & 18,2 & 2,4 & 33,5 \\
\hline średniowysoki & 73,1 & 4,2 & 4,2 & 18,6 \\
\hline wysoki & 85,9 & 1,0 & 3,7 & 9,3 \\
\hline
\end{tabular}

* Niski: mniej niż 1,006 dolarów; średni 1,007-3,975 dolarów; średniowysoki 3,976-12,275; wysoki, pow. 12,276.

Źródło: opracowanie na podstawie: Gindling, Newhouse (2013). Self-employment in developing world. Background paper for the world development report

W świetle ostatnich statystyk odsetek samozatrudnionych dla krajów OECD w roku 2011 wynosił 15,8\%. Dane dla poszczególnych krajów wskazują na jego dużą różnorodność. Do państw, w których odsetek pracujących na własny rachunek jest względnie niski (poniżej $10 \%)$, należą: USA (6,8\%), Norwegia (6,9\%), Estonia (8,6\%), Kanada (8,9\%) i Dania $(9,1 \%)$. Najwyższe odsetki samozatrudnionych (powyżej 20\%) notuje się w: Turcji (37,1\%), Grecji $(36,8 \%)^{2}$, Meksyku (33,7\%), Korei Płd. (28,8\%), Brazylii (27,1\%), Włoszech (25,1\%), Polsce $(22,4 \%)$ i Portugali $(21,9 \%)$. Polska z takim odsetkiem samozatrudnionych plasuje się zatem na trzecim miejscu wśród krajów Unii Europejskiej.

W latach 2000-2012 odsetek samozatrudnionych wykazywał tendencje do wzrostu tylko w trzech krajach - w Czechach, Holandii i Słowacji. W większości krajów następował niewielki spadek pracujących na własny rachunek. Znaczące spadki (powyżej 5 p.p.) wystąpiły w Turcji (14,3 p.p.), Korei Płd. (8,6 p.p.), w Grecji (o 5,2 p.p.), na Islandii (o 5,3 p.p.), w Polsce (5,0 p.p.). W każdym z krajów, z wyjątkiem Turcji i Meksyku, w populacji pracujących na własny rachunek przeważali mężczyźni (OECD, 2014) (tab. 2).

Sytuacja na krajowym rynku pracy wpływa na poziom mobilności pracowników, w tym na ich zagraniczne migracje zarobkowe. Te z kolei sprzyjają nasilaniu się przedsiębiorczości indywidualnej w populacji imigrantów. Ich wyższa od średniej skłonność do samozatrudnienia została rozpoznana i naukowo wyjaśniona już w latach 70. XX w. przez E. Bonacich (1973) w tzw. teorii pośredników (ang. middleman minority theory) i rozwinięta w pracach A. Portesa i L. Jensena (1989).

${ }^{2}$ Badania Eurobarometru wskazują, że w Grecji i na Cyprze odnotowano największy odsetek respondentów, którzy stwierdzili, iż woleliby pracować na własny rachunek (ok. 63\%), niż być pracownikami. Natomiast w takich krajach, jak Irlandia, Litwa, Bułgaria, Włochy, Rumunia, Polska to deklarowane zainteresowanie było niższe o ok. $10 \%$. Wskazane różnice w zadeklarowaniu chęci bycia osobą prowadzącą własną działalność w krajach o bardzo zbliżonym poziomie rozwoju gospodarczego badacze tłumaczą faktem dużego sentymentu do samozatrudnienia i sprzyjającym systemem polityki rynku pracy wobec przedsiębiorców. 
Tab. 2. Samozatrudnienie w krajach OECD w latach 2000 i 2012 (\%)

\begin{tabular}{|c|c|c|c|c|c|c|}
\hline \multirow{2}{*}{ Kraj } & \multicolumn{2}{|c|}{ Kobiety } & \multicolumn{2}{|c|}{ Mężczyźni } & \multicolumn{2}{|c|}{ Razem } \\
\hline & 2000 & 2012 & 2000 & 2012 & 2000 & 2012 \\
\hline Australia & 10,4 & 8,3 & 16,1 & 12,3 & 13,6 & 10,5 \\
\hline Austria & 12,2 & 10,8 & 13,9 & 15,6 & 13,1 & 13,3 \\
\hline Belgia & 13,5 & 10,5 & 17,5 & 17,6 & 15,8 & 14,3 \\
\hline Chile & 24,5 & .. & 32,4 &.. & 29,8 & .. \\
\hline Czechy & 10,2 & 13,5 & 19,1 & 22,3 & 15,2 & 18,5 \\
\hline Dania & 5,7 & 5,6 & 12,1 & 12,3 & 9,1 & 9,1 \\
\hline Estonia & 6,4 & 5,1 & 11,6 & 12,3 & 9,1 & 8,6 \\
\hline Finlandia & 9,2 & 8,9 & 17,8 & 18,2 & 13,7 & 13,6 \\
\hline Francja & 7,2 & .. & 11,0 & .. & 9,3 & .. \\
\hline Grecja & 38,9 & 31,2 & 43,7 & 40,6 & 42,0 & 36,8 \\
\hline Hiszpania & 16,6 & 13,0 & 22,2 & 21,5 & 20,2 & 17,6 \\
\hline Holandia & 9,4 & 11,7 & 12,6 & 18,5 & 11,2 & 15,3 \\
\hline Irlandia & 8,6 & 7,5 & 25,9 & 24,8 & 18,8 & 16,7 \\
\hline Islandia & 11,0 & 9,0 & 24,0 & 16,2 & 18,0 & 12,7 \\
\hline Izrael & 9,3 &.. & 18,3 & .. & 14,2 &.. \\
\hline Japonia & 18,3 & 10,7 & 15,5 & 12,6 & 16,6 & 11,8 \\
\hline Kanada & 9,2 & 8,0 & 11,8 & 9,7 & 10,6 & 8,9 \\
\hline Korea Płd. & 38,4 & 26,0 & 35,7 & 29,8 & 36,8 & 28,2 \\
\hline Luksemburg & 6,9 &.. & 7,7 &.. & 7,4 &.. \\
\hline Meksyk & 35,2 & 35,1 & 36,4 & 32,9 & 36,0 & 33,7 \\
\hline Niemcy & 7,9 & 8,3 & 13,4 & 14,4 & 11,0 & 11,6 \\
\hline Norwegia & 4,8 & 4,1 & 9,8 & 9,4 & 7,4 & 6,9 \\
\hline Nowa Zelandia & 14,5 & 12,2 & 25,6 & 20,0 & 20,6 & 16,4 \\
\hline Polska & 24,8 & 19,2 & 29,5 & 25,0 & 27,4 & 22,4 \\
\hline Portugalia & 24,4 & 17,5 & 27,4 & 25,8 & 26,0 & 21,9 \\
\hline Słowacja & 4,6 & 9,9 & 10,8 & 19,8 & 8,0 & 15,5 \\
\hline Słowenia & 13,0 & 12,8 & 18,6 & 19,2 & 16,1 & 16,2 \\
\hline Stany Zjednoczone & 6,1 & .. & 8,6 & .. & 7,4 & 6,8 \\
\hline Szwajcaria & 12,3 & 10,5 & 13,9 & 10,7 & 13,2 & 10,7 \\
\hline Szwecja & 5,7 & 5,9 & 14,5 & 14,6 & 10,3 & 10,5 \\
\hline Turcja & 64,7 & 45,7 & 46,5 & 33,5 & 51,4 & 37,1 \\
\hline Węgry & 10,5 & 8,8 & 19,1 & 14,3 & 15,2 & 11,7 \\
\hline Wielka Brytania & 8,3 & 9,6 & 16,7 & 19,0 & 12,8 & 14,6 \\
\hline Włochy & 22,0 & 18,3 & 32,3 & 30,0 & 28,5 & 25,1 \\
\hline OECD & 15,1 & .. & 19,6 & .. & 17,7 &.. \\
\hline
\end{tabular}

Źródło: opracowanie na podstawie: OECD Factbook 2014

Do przedsiębiorców - pośredników zalicza się tych migrantów, którzy zakładają małe przedsiębiorstwa handlowe lub usługowe, działające $\mathrm{w}$ biednych lub postrzeganych za 
niebezpieczne dzielnicach. Przyczyną podjęcia przez nich decyzji o założeniu działalności gospodarczej jest segmentacja rynku pracy i relatywnie małe szanse na pozyskanie zatrudnienia w sektorze pierwotnym. Samozatrudnienie kreuje dla nich wówczas możliwości zbliżone do sektora pierwotnego (przez wyłonienie się tzw. trzeciego sektora), często niedostępnego dla mniejszości etnicznych czy nowo przybyłych imigrantów (Bonacich, 1973; Portes, Jensen, 1989; Kopycińska, 2013). Ci przedsiębiorcy, którzy na tyle rozwinęli swoją działalność, że potrzebują zatrudnić pracowników, wykorzystują w tym celu zasoby siły roboczej innych migrantów, skłonnych pracować nieformalnie i za względnie niskie wynagrodzenie. Takim strategiom służy koncentracja przedsiębiorstw etnicznych na określonym obszarze (dzielnica miasta), które w ten sposób zaspokajają zarówno potrzeby własnej grupy, jak i społeczeństwa przyjmującego (Wysieńska, 2012).

\section{Determinanty pozaekonomiczne}

Różnice w odsetkach samozatrudnionych i ich strukturze płciowej w krajach o zbliżonym poziomie gospodarczym wskazują na to, że przedsiębiorczość indywidualna jest uwarunkowana przez wiele pozaekonomicznych czynników, zwanych także determinantami indywidualnymi. W dalszej części artykułu zamieszczono przegląd wyników badań teoretycznych i empirycznych na temat wpływu takich czynników pozaekonomicznych na poziom samozatrudnienia, jak: wiek, płeć, stan zdrowia, stan cywilny, posiadanie dzieci, wpływ innych osób, zwłaszcza członków rodziny, wykształcenie, cechy osobowości (zdolności przedsiębiorcze, skłonność do ryzyka), motywacje.

\section{Wiek}

Badania ustalające wpływ wieku na poziom przedsiębiorczości indywidualnej dowodzą tzw. U-kształtnej zależności wieku i samozatrudnienia. Jest ona konsekwencją trzech głównych czynników. Po pierwsze, ludzie z wiekiem akumulują kompetencje, nabywają nowe kwalifikacje, budują kapitał społeczny oraz finansowy. Z tego powodu, im większe są wszystkie wymienione „aktywa ludzkie”, tym rośnie szansa u ludzi odczuwających chęć kontynuowania swojej ścieżki kariery zawodowej przez samozatrudnienie na wdrożenie tego zamiaru w życie (Simoes i in., 2013).

Po drugie, wiek jest pozytywnie skorelowany z rosnącą potrzebą elastycznych godzin pracy, wynikającą z różnych przesłanek, w tym także z nasilających się własnych lub innych bliskich członków rodziny problemów zdrowotnych. W przypadku niemożności wynegocjowania elastycznego czasu pracy u pracodawcy osoby takie decydują się na samozatrudnienie po to, aby móc pogodzić potrzeby lub ograniczenia prywatne z wolą dalszej aktywności zawodowej.

Trzecia argumentacja wzrostu prawdopodobieństwa pracy na własny rachunek wraz Z wiekiem odnosi się do chęci opóźnienia momentu opuszczenia rynku pracy (przejścia na emeryturę). Jak wskazują badania, coraz powszechniejsze staje się w populacji osób starszych przejście na samozatrudnienie i traktowanie go jako swoistego pomostu pomiędzy dotychczasową karierą zawodową a ostatecznym wyjściem z rynku pracy (Cahill i in., 2006; Kerr, Armstrong-Stassen, 2011).

Występują także czynniki negatywnie wpływające na prawdopodobieństwo samozatrudnienia wśród osób starszych. Są to: malejąca z wiekiem gotowość do podejmowania ryzyka, 
słabsza kondycja fizyczna i psychiczna, mniejsza odporność na stres oraz relatywnie krótszy czas na odzyskanie kapitału zainwestowanego w rozpoczęcie własnej działalności (Hintermaier, Steinberger, 2005).

Ustalona została również zależność między wiekiem i bezpośrednio z nim związaną długością kariery zawodowej a prawdopodobieństwem podjęcia pracy na własny rachunek jako firma jednoosobowa lub jako przedsiębiorca zatrudniający pracowników. Stwierdzono, że wraz z wiekiem i doświadczeniem na rynku pracy rośnie wśród samozatrudnionych odsetek firm jednoosobowych (Lechmann, Schnabel, 2011).

\section{Płeć}

Badania prowadzone w krajach wysoko rozwiniętych wskazują na istnienie dużych różnic w prawdopodobieństwie wyboru ścieżki przedsiębiorcy pomiędzy kobietami a mężczyznami, na korzyść tych ostatnich. Stan ten pozostaje w opozycji do teorii dyskryminacji, która zawiera racjonalne wyjaśnienie spodziewanego, wyższego zainteresowania samozatrudnieniem u kobiet. Nierówne traktowanie kobiet w pracy i niższe wynagrodzenie powinno je skłaniać do samozatrudnienia, które może być strategią ucieczki od niesatysfakcjonującej sytuacji w pracy najemnej (Williams, 2012).

Wśród kobiet o zróżnicowanym poziomie wykształcenia i kraju pochodzenia stwierdzono, że ich motywacje i oczekiwania wobec pracy zawodowej są odmienne od oczekiwań mężczyzn. Mężczyźni częściej pragną wysokich dochodów, prestiżu i niezależności, co przypisuje się prowadzeniu własnej działalności gospodarczej. Kobietom bardziej zależy na zachowaniu równowagi między pracą zawodową a życiem prywatnym (rodzinnym) i na stabilności, a warunki te częściej spełniają prace najemne (Clark, 1997).

Niższe odsetki kobiet wśród populacji samozatrudnionych wynikają - jak wskazują badania - przede wszystkim $\mathrm{z}$ ich większej niechęci do podejmowania ryzyka w porównaniu z mężczyznami. Panowie mają bardziej rozległe sieci kontaktów społecznych, w dużej mierze zbudowanych w trakcie swoich działań zawodowych, co ułatwia im znalezienie nabywców na dobra lub usługi wytwarzane w pracy na własny rachunek. Role życiowe kobiet (macierzyństwo) i wynikające z nich przerwy w pracy zawodowej, na ogół większe niż u mężczyzn, a także zaangażowanie w życie rodzinne nie sprzyjają budowaniu podobnie dużej sieci kontaktów zawodowych. Ponadto kobiety, kiedy już wybiorą samozatrudnienie, są bardziej ostrożne w przyjmowanych strategiach i skali działania, ogniskują swoje działania w branżach, w których są nadreprezentowane (usługi, handel). $Z$ tego powodu mają mniejsze szanse na rozwijanie firmy $\mathrm{z}$ dużym sukcesem. Istotna jest również struktura ukończonych przez kobiety kierunków kształcenia, które predestynują je częściej do pracy najemnej. Kobiety także rzadziej poszukują zewnętrznych źródeł finansowania, polegając przede wszystkim na swoich aktywach, co często ogranicza, a niekiedy bywa poważną barierą dla dobrego startu w samozatrudnienie (nie zainwestowano odpowiednich środków w infrastrukturę, sprzęt, reklamę itp.) (Taniguchi, 2002; Georgellis, Wall, 2005; Sena i in., 2012; Williams, 2012).

\section{Stan zdrowia}

Ustalenia dotyczące wpływu stanu zdrowia na poziom samozatrudnienia są niejednoznaczne. Dyskryminacja osób mających problemy zdrowotne czy niepełnosprawnych przez pracodawców jest uznawana za impuls do poszukiwania przez nich alternatywnych form 
zatrudnienia. Wykonano zarówno badania dowodzące większego zainteresowania podjęciem pracy na własny rachunek wśród osób z problemami zdrowotnymi, jak i takie, które egzemplifikują odwrotną sytuację. Różnice wynikają w dużej mierze z polityki rynku pracy i polityki socjalnej, np. wobec osób niepełnosprawnych. Charakter tej polityki może, znacznie intensywniej niż sam stan zdrowia, zachęcać do pracy na własny rachunek lub studzić takie zamiary, a w związku z tym może również zmuszać do określonych zachowań na rynku pracy (Parker, Rougier, 2007; Jones, Latreille, 2011).

\section{Stan cywilny, posiadanie dzieci}

Wpływ stanu cywilnego na zachowania na rynku pracy, w tym na samozatrudnienie, cieszy się bardzo dużym zainteresowaniem badaczy reprezentujących różne dyscypliny naukowe. Do najważniejszych aktualnych ustaleń w tym zakresie należy zaliczyć to, że pozostawanie w związku sprzyja wybieraniu ścieżki samozatrudnienia, co związane jest ze wsparciem materialnym i niematerialnym, którego udziela partner/współmałżonek zarówno na początku, jak i w trakcie prowadzenia działalności gospodarczej. Pracujący współmałżonek zwiększa komfort i poczucie bezpieczeństwa osoby samozatrudnionej przez zapewnienie stałych środków utrzymania i umożliwienie przetrwania okresowych trudności finansowych. Ponadto może on partycypować w prowadzonym biznesie, np. pracować okresowo, nieodpłatnie i z największym zaangażowaniem w podejmowane działania, ponieważ kieruje nim pragnienie pomocy osobie najbliższej w osiągnięciu założonych celów. Aspekt oddziaływania niematerialnego jest nie mniej ważny na każdym etapie samozatrudnienia. Współmałżonek może być szczerym, krytycznym i długofalowym źródłem emocjonalnego wsparcia w toku działań towarzyszących tej formie zatrudnienia (Özcan, 2011).

Mniej jednoznaczne zdanie na temat korzystnego wpływu współmałżonka na samozatrudnienie przedstawione zostało w neoklasycystycznej teorii rodziny. Teoria ta zakłada, że ten małżonek, który „specjalizuje się” w czynnościach domowych, automatycznie mniej uwagi i czasu poświęca na pracę zawodową. Samozatrudnienie - jako szczególnie angażująca forma realizacji ścieżki zawodowej - wydaje się mało realne w przypadku tej osoby, która wykonuje większość czynności domowych. Fakt często nieproporcjonalnego (na niekorzyść kobiet) podziału obowiązków domowych w wielu rodzinach bardziej zatem sprzyja samozatrudnieniu małżonków płci męskiej (Becker, 1991).

Z drugiej strony, ostatnio przeprowadzone badania wyraźnie dowodzą, że zmiany społeczno-demograficzne skutkujące niestabilnością związków małżeńskich, wzrostem związków nieformalnych, rozwodów, partnerskim podziałem obowiązków rodzinnych osłabiają wpływ stanu cywilnego na samozatrudnienie, jednak przy dalszej pozytywnej korelacji między stanem małżeńskim a odsetkiem samozatrudnionych (Macieira, 2009; Özcan, 2011).

W badaniach empirycznych dominują też konkluzje o korzystnym wpływie ojcostwa/macierzyństwa na podjęcie drogi samozatrudnienia. Po pierwsze, posiadanie dzieci motywuje część rodziców do samozatrudnienia, ponieważ daje im ono szansę na osiągnięcie wyższych dochodów i tym samym stwarza lepsze warunki finansowe do wychowania oraz wykształcenia potomstwa. Po drugie, wychowywanie i opieka nad dziećmi często utrudnia pracę na etacie, wykonywaną w stałych godzinach i trwającą dość długo, co skłania rodziców do samozatrudnienia umożliwiającego im bardziej elastyczny czas pracy. Po trzecie, dzieci-nastolatki mogą pomagać w prowadzeniu biznesu, co może przyczyniać się do obniżenia kosztów i podniesienia jakości wykonywanych dóbr lub usług (Dawson i in., 2009). 
W innych opracowaniach wskazuje się jednak, że bycie rodzicem zmniejsza prawdopodobieństwo samozatrudnienia, gdyż wymaga ono bardzo dużego zaangażowania (czasowego), co bywa niemożliwe do pogodzenia z obowiązkami rodzinnymi. Ponadto podkreślono, że poczucie odpowiedzialności za rodzinę może nasilać niechęć do podejmowania ryzyka, które wiąże się z prowadzeniem działalności bardziej niż praca etatowa (Fairchild, 2009).

\section{Wpływ innych osób, zwłaszcza członków rodziny (zaplecze rodzinne), tradycje przedsiębiorcze $w$ rodzinie}

Tradycje przedsiębiorcze w rodzinie lub małżeństwo z osobą z rodziny przedsiębiorców odgrywają bardzo ważną rolę w podejmowaniu samozatrudnienia. Wiedza i kompetencje, niejako mimowolnie nabyte w środowisku rodziny, nasiąknięcie atmosferą przedsiębiorczości, kapitał kontaktów społecznych, zwłaszcza posiadanie rodziców - przedsiębiorców sprzyja wyborowi pracy na własny rachunek (Kirkwood, 2007). Klimat przedsiębiorczości w rodzinie, pozytywne doświadczenia rodziców w prowadzeniu własnej firmy zdecydowanie uprawdopodabniają powielenie ich ścieżki kariery zawodowej przez samozatrudnienie u dzieci. Doświadczenie przedsiębiorczości rodzinnej buduje w młodzieży przekonanie o wykonalności i realności ścieżki zawodowej przez działalność gospodarczą (Wach, 2015).

Ponadto, w sytuacji gdy rodzice prowadzą/prowadzili własną działalność gospodarczą, ich dzieci zakładały swoje firmy wcześniej niż rówieśnicy, a przyjęte przez nich strategie działania były skuteczniejsze. Jest to głównie efekt współuczestniczenia w prowadzeniu działalności przez rodziców, co skutkuje nie tylko naśladowaniem ich stylu pracy, lecz także krytyczną refleksją w tym zakresie. W ten sposób gromadzi się również bagaż bezpośrednich doświadczeń i obserwacji, które zwiększają szanse na długofalowe powodzenie we własnej karierze zawodowej przedsiębiorcy (Macieira, 2009). Zależność ta nie odnosi się wyłącznie do więzów krwi, ale również np. do związków małżeńskich (Blanchflower, 2000; Livanos, 2009). Jak wskazują badania, nawet trudności członków rodziny w toku prowadzenia własnej działalności gospodarczej nie mają negatywnych reperkusji w postaci zamiany decyzji pokolenia dzieci w zakresie samozatrudnienia (De Wit, van Winden, 1989).

\section{Wykształcenie}

Studia teoretyczne oraz badania empiryczne zgodnie wskazują na znaczący wpływ poziomu i kierunku wykształcenia na samozatrudnienie w krajach rozwiniętych oraz na mniej istotny wpływ tego czynnika w krajach słabo rozwiniętych. Wiele krajów europejskich zaczęło też włączać przedsiębiorczość do programów kształcenia na różnych poziomach edukacyjnych. Około dwie trzecie tych krajów prowadzi edukację w zakresie przedsiębiorczości w szkołach podstawowych, blisko połowa ma takie kursy w szkołach średnich. Rośnie też zainteresowanie przedsiębiorczością w edukacji akademickiej (van der Zwan i in., 2013).

Pozytywna korelacja poziomu wykształcenia i odsetka samozatrudnienia wynika $\mathrm{z}$ faktu, że im większy jest zasób kompetencji (rosnący z każdym kolejnym poziomem edukacji), tym niższe, szczególnie na pierwszym etapie, są koszty inicjowanej działalności gospodarczej (Henley, 2005; Dawson i in., 2009; Falk, Leoni, 2009). Wraz ze wzrostem wykształcenia zwiększa się też prawdopodobieństwo stania się pracodawcą. Jak bowiem zakłada E. Lazear w teorii Jacks-of-all-trades ('spec od wszystkiego, mistrz od niczego'), bycie przedsiębiorcą wymaga obeznania w wielu dziedzinach i posiadania o nich aktualnej, podstawowej wiedzy, która powinna być stale rozbudowywana i odświeżana. Przedsiębiorca nie musi być zatem ekspertem 
w określonej branży, ponieważ ekspertami powinni być jego pracownicy, którym są wyznaczane określone zadania, ale powinien mieć taki zasób wiedzy z obszarów kompetencji swoich pracowników, by mógł skutecznie kierować i kontrolować efekty ich pracy ${ }^{3}$. Im dłużej człowiek się kształci, tym łatwiej przychodzi mu przyswajanie wiedzy. Korzystny wpływ wyższego wykształcenia na odsetek samozatrudnionych potwierdzają badania, wskazujące na większe możliwości bycia przedsiębiorcą w grupie tzw. talented workers, wśród których bezsprzecznie dominują osoby posiadające dyplom uczelni wyższej (Tyrowicz i in., 2015).

Te teoretyczne założenia znajdują potwierdzenie w badaniach empirycznych ustalających, że absolwenci studiów wyższych z większym prawdopodobieństwem założą własną działalność gospodarczą (Cooper i in., 1994). Posiadanie wyższego wykształcenia ma pozytywny wpływ na odsetek samozatrudnienia i wysoką nadreprezentatywność osób z dyplomem szkoły wyższej w strukturze pracodawców (Bates, 1990; Grotkowska, Sztanderska, 2007). Dowiedziono także, że edukacja wyższa wyraźnie pozytywnie oddziałuje na podejmowanie inicjatywy gospodarczej, zwłaszcza bezpośrednio po zakończeniu studiów. Już po czterech latach od uzyskania dyplomu nie ujawniał się statystycznie istotny wpływ umiejętności nabytych na studiach na podjęcie samozatrudnienia (Greene, Saridakis, 2008; Zbierowski, 2014).

Podobnie liczne są prace, które dowodzą, że pozytywna korelacja pomiędzy wyższym wykształceniem a samozatrudnieniem jest przynajmniej niejednoznaczna. Chronologicznie najwcześniejszym kontrargumentem było to, że przed długi okres edukacji dyplom, stopień i kwalifikacje w znacznie większym stopniu warunkowały wysoki status podmiotu na najemnym rynku pracy, niż wpływały na podejmowanie decyzji o założeniu własnej działalności gospodarczej (Piróg, 2014).

\section{Cechy osobowości i motywacje}

W pracach poświęconych wpływowi wybranych cech osobowości na prawdopodobieństwo pracy na własny rachunek za wiodące uznaje się: gotowość do podejmowania ryzyka, pewność siebie, wolę sukcesu, potrzebę autonomii, wysoką samoocenę, asertywność, niezależność, narcyzm (Simoes i in., 2013).

Empirycznie stwierdzono, że samozatrudnienie jest bardziej prawdopodobne u osób ekstrawertycznych, otwartych na nowe doświadczenia, ugodowych, sumiennych i stabilnych emocjonalnie (Caliendo i in., 2011).

Badania pozwalają na wskazanie siedmiu kluczowych motywacji, które wpływają na podjęcie decyzji o samozatrudnieniu i sprzyjają długofalowemu funkcjonowaniu na rynku pracy osób pracujących na własny rachunek, które często występują również w roli pracodawcy:

1. idiosynkratyczne (ang. idiosyncratic entrepreneurship) dotyczą osób, które decydują się na samozatrudnienie, ponieważ mają najczęściej wrodzone cechy i zdolności kognitywne w zakresie przedsiębiorczości, charakteryzują się ponadprzeciętną wolą walki i osiągnięć, bardzo wysokim poziomem optymizmu, naturalnym zmysłem przywódczym. Osoby te tylko w samozatrudnieniu znajdują spełnienie zawodowe;

2. racjonalne - popytowe (ang. market-facing opportunity entrepreneurship), wynikające $\mathrm{z}$ analizy popytu na określone dobra/usługi i chęci wypełnienia ustalonej luki. Osoby te często decydują się na rozpoczęcie działalności gospodarczej niezwiązanej z ich

\footnotetext{
${ }^{3}$ Pracownik nie musi mieć szerokiej wiedzy, ale powinien być dobrym specjalistą w swojej, niekiedy wąskiej, dziedzinie. Potwierdziły to badania, w których ustalono, że wysokie wynagrodzenia pracowników są determinowane przez tę wąską specjalizację, czego nie odnotowano wśród pracodawców.
} 
dotychczasowym doświadczeniem zawodowym i ukończonym kierunkiem kształcenia, ponieważ na nie - jak wynika $\mathrm{z}$ ich rozeznania - nie ma popytu;

3. racjonalne - podażowe (ang. professional entrepreneurship) dotyczą osób, które wybierają samozatrudnienie, aby móc samodzielnie decydować o dołączaniu się do zespołów profesjonalnych (jako podwykonawcy) i w ten sposób zdobywać coraz większe doświadczenie zawodowe w danej branży. Motywacją jest chęć efektywnego wykorzystania własnych kompetencji i ich bardziej dynamiczny rozwój;

4. rodzinne (ang. family entrepreneurship) odnoszą się do tych przedsiębiorców, którzy dołączają lub przejmują działalność gospodarczą od innych członków rodziny. Motywacją jest przede wszystkim chęć kontynuacji dotychczasowych dokonań, przeprowadzenie zmian mających na celu bardziej dynamiczny rozwój firmy;

5. psychologiczne - niezależności (ang. independence-seeking) cechują osoby stawiające na pierwszym miejscu potrzebę niezależności. Ich motywacje do samozatrudnienia wynikają głównie z intensywnej potrzeby bycia niezależnym, a w znikomym stopniu mają uwarunkowania ekonomiczne;

6. filozoficzne/przyjętego stylu życia (ang. lifestyle entrepreneurs) są prezentowane głównie przez kobiety i młodych ludzi, którzy świadomie wybierają samozatrudnienie z wewnętrznej potrzeby (nie konieczności) zachowania równowagi między pracą zawodową a życiem rodzinnym/osobistym, a która byłaby niemożliwa do realizacji w pracy na etacie;

7. potrzeby zmiany (ang. reward-seeking entrepreneurship) spotykane najczęściej na początku ścieżki kariery zawodowej u ludzi, którzy rezygnują z pracy na etacie, chcąc przez samozatrudnienie zmienić na lepsze swoje warunki pracy i poziom dochodów (Dawson i in., 2009).

\section{Wnioski końcowe}

Przeprowadzone studia prac teoretycznych i empirycznych po raz kolejny potwierdzają fakt, że ludzie mogą zdecydować się na samozatrudnienie z wielu powodów. Dla części osób wybór pracy na własny rachunek jest efektem ich przedsiębiorczej postawy, potrzeby zrealizowania indywidualnych aspiracji, planów, wyrażenia kreatywności i niezależności. Dla innych ta forma zatrudnienia stanowi alternatywę dla pracy etatowej, której nie mogą wykonywać ze względu na osobiste uwarunkowania rodzinne i życiowe. Dla jeszcze innych bywa to jedyny sposób na uniknięcie bezrobocia.

Na podstawie dokonanego przeglądu literatury można stwierdzić, że w grupie czynników ekonomicznych dowiedziono występowania dodatniej korelacji między samozatrudnieniem a:

- niekorzystną sytuacją na rynku pracy,

- trudnościami z przejściem do pierwotnego segmentu pośród migrantów zarobkowych,

- niższymi dochodami z alternatywnych form aktywizacji zawodowej,

- posiadaniem wyższego kapitału (finansów),

- możliwością swobodnego przemieszczania się pracowników poza granice kraju.

W grupie czynników pozaekonomicznych ustalono większą skłonność do zakładania własnej działalności:

- wśród mężczyzn i osób młodych (do 40 roku życia),

- wśród dorosłych dzieci (wnuków) przedsiębiorców, 
- wówczas, kiedy podjęcie samozatrudnienia zyskuje akceptację najbliższego otoczenia,

- w populacji wykazującej motywacje idiosynkratyczne oraz popytowo-podażowe,

- przez osoby posiadające wyższe wykształcenie.

Przedstawiona synteza wyników badań empirycznych, weryfikujących wpływ czynników ekonomicznych i pozaekonomicznych na poziom samozatrudnienia, wydaje się uprawniać do wskazania dalszych kierunków badań w tym nurcie. Jednym z nich jest potrzeba eksploracji roli edukacji w procesie podejmowania decyzji o rozpoczęciu działalności gospodarczej i wdrażania tego zamiaru do działań praktycznych. Pomimo rosnącego zainteresowania systemu edukacji przedsiębiorczością, przejawiającego się we wprowadzaniu kursów o tej tematyce do programów kształcenia na różnych poziomach, brak jest naukowej oceny realnego oddziaływania edukacji w zakresie przedsiębiorczości na podejmowanie samozatrudnienia. Odczuwa się także niedobór prac poświęconych metodom badań tego typu problemów. Luki te nie wynikają z nieświadomości potrzeby takich badań wśród specjalistów, ale z czasochłonności (niezbędne badania co najmniej kilkunastoletnie), kosztochłonności, trudności organizacyjnych i z wysokiego ryzyka osiągnięcia niewystarczającego poziomu responsywności, co uniemożliwia przeprowadzenie analiz spełniających wszystkie wymagania stawiane rzetelnym badaniom naukowym. $Z$ drugiej strony, ich podjęcie wydaje się być kluczowe nie tylko z punktu widzenia diagnozy implementacji efektów kształcenia z przedsiębiorczości do praktyki, weryfikacji skuteczności przyjmowanych strategii metodycznych oraz dydaktycznych w trakcie realizowania kursów, lecz także budowania nowoczesnych teorii efektywnego kształcenia w tym zakresie.

Literatura

References

Bates, T. (1990). Entrepreneur human capital inputs and small business longevity. The Review of Economics and Statistics, 4, 551-559.

Becker, G. (1991). A treatise on the family. Cambridge: Harvard University Press.

Blanchflower, D.G. (2000). Self-employment in OECD countries. Labour Economics, 7(5), 471-505.

Bonacich, E. (1973). A theory of middleman minorities. American Sociological Review, 38(5), 583-594.

Cahill, K., Giandrea, M., Quinn, J. (2006). Retirement patterns from career employment. The Gerontologist, 46(4), 514-523. DOI: 10.1093/geront/46.4.514

Caliendo, M., Fossen, F., Kritikos, A. (2011). Personality characteristics and the decision to become and stay self-employed. IZA Discussion Paper, 5566.

Chodyński, A. (2008). Przedsiębiorczość i innowacyjność a kompetencje - aspekty strategiczne. Zeszyty Naukowe Szkoły Humanitas, 2, 31-39.

Chyba, Z. (2015). Rola potencjału technologicznego w kształtowaniu przedsiębiorczości technologicznej. Kwartalnik Nauk o Przedsiębiorstwie, 4, 27-35.

Clark, A.E. (1997). Job satisfaction and gender: why are women so happy at work? Labour Economics, 4(4), 341-372. DOI: 10.1016/S0927-5371(97)00010-9

Cooper, A.C., Gimeno-Gascon, F.J., Woo, C.Y. (1994). Initial human capital and financial capital as predictors of a new venture performance. Journal of Business Venturing, 9, 371-395. DOI: 10.1016/0883-9026(94)90013-2

Czerniachowicz, B. (2011). Uwarunkowania przedsiębiorczości korporacyjnej na podstawie przedsiębiorstw z województwa zachodniopomorskiego. Studia i Prace Wydziału Nauk Ekonomicznych i Zarządzania, Uniwersytet Szczeciński, 21, 197-206.

Dawson, Ch., Henley, A., Latreille, P. (2009). Why do individuals choose self-employment? IZA Discussion Papers, 3974. 
De Wit, G., van Winden, F.A. (1989). An empirical analysis of self-employment in the Netherlands. Small Business Economics, 1(4), 263-272. DOI: 10.1007/BF00393805

Douglas, E., Shepherd, D. (2002). Self-employment as a career choice: attitudes, entrepreneurial intentions, and utility maximization. Entrepreneurship Theory and Practice, 26(3), 81-90.

Fairchild, G. (2009). Residential segregation influences on the likelihood of ethnic self-employment. Entrepreneurship Theory and Practice, 33(2), 373-395. DOI: 10.1111/j.1540-6520.2009.00295.x

Falk, M., Leoni, T. (2009). Characteristics of self-employment among university graduates. Applied Economics Letters, 16(10), 1065-1071. DOI: 10.1080/13504850701335319

Georgellis, Y., Wall, H. (2005). Gender differences in self-employment. International Review of Applied Economics, 19(3), 321-342. DOI: 10.1080/02692170500119854

Gindling, T.H., Newhouse, D. (2013). Self-employment in developing world. Background paper for the world development report 2013.

Greene, F., Saridakis, G. (2008). The role of higher education skills and support in graduate self-employment. Studies in Higher Education, 33(6), 653-672. DOI: 10.1080/03075070802457082

Grotkowska, G., Sztanderska, U. (2007). Samozatrudnienie. W: Edukacja dla pracy. Raport o rozwoju społecznym Polska 2007. Warszawa: UNDP, 115-116.

Henley, A. (2005). Job creation by the self-employed: the roles of entrepreneurial and financial capital. Small Business Economics, 25, 175-196. DOI: 10.1007/s11187-004-6480-1

Hintermaier, T., Steinberger, T. (2005). Occupational choice and the private equity premium puzzle. Journal of Economic Dynamics and Control, 29(10), 1765-1783. DOI: 10.1016/j.jedc.2004.11.001

Jones, M., Latreille, P. (2011). Disability and self-employment: evidence for the UK. Applied Economics, 43(27), 4161-4178. DOI: 10.1080/00036846.2010.489816

Kaczorowski, P. (2011). Samozatrudnienie jako forma przedsiębiorczości w województwie łódzkim - ocena dotychczasowego stanu, bariery i perspektywy. Łódź: Wydawnictwo Naukowe UŁ.

Kerr, G., Armstrong-Stassen, M. (2011). The bridge to retirement: older workers' engagement in post-career entrepreneurship and wage-and-salary employment. Journal of Entrepreneurship, 20(1), 55-76. DOI: $10.1177 / 097135571002000102$

Kirkwood, J. (2007). Igniting the entrepreneurial spirit: is the role parents play gendered? International Journal of Entrepreneurial Behaviour and Research, 13(1), 39-59. DOI: 10.1108/13552550710725174

Kopycińska, D. (2013). Determinanty przedsiębiorczości indywidualnej emigrantów zarobkowych z województwa zachodniopomorskiego. Przegląd Zachodniopomorski, 3(1), 137-156.

Korpysa, J. (2011). Popytowo-podażowy model przedsiębiorczości indywidualnej. Ekonomika i Organizacja Przedsiębiorstwa, 6(737), 34-41.

Koźmiński, A.K. (2004). Zarządzanie w warunkach niepewności. Warszawa: Wydawnictwo Naukowe PWN.

Kraska, E. (2010). Uwarunkowania rozwoju przedsiębiorczości w Polsce. Studia i Materiały. Miscellanea Oeconomicae, 14(1), 247-257.

Kunasz, M. (2013). Analiza determinant wyboru momentu rozpoczęcia własnej działalności gospodarczej. Management and Business Administration. Central Europe, 22, 65-79. DOI: 10.7206/mba. ce.2084-3356.99

Kunasz, M. (2014). Skłonność do samozatrudnienia i determinanty wyboru docelowej formy aktywności zawodowej w świetle wyników badań studentów. Optimum. Studia Ekonomiczne, 2(68), 116-131.

Lechmann, D., Schnabel, C. (2011). Are the self-employed really Jacks-of-all-trades? Testing the assumptions and implications of Lazear's theory of entrepreneurship with German data. IZA Discussion Paper, 6157.

Lemańska-Majdzik, A. (2008). Rola osoby przedsiębiorcy w rozwoju przedsiębiorczości indywidualnej. W: G. Maniak (red.), Problemy ekonomii i polityki gospodarczej (materialy konferencyjne). Szczecin: Wydawnictwo Naukowe US, 136-146.

Lemańska-Majdzik, A. (2013). Powody prowadzenia własnej działalności gospodarczej małych firm. Zeszyty Naukowe Wyższej Szkoły Humanitas. Zarządzanie, 1, 48-56. 
Livanos, I. (2009). What determines self-employment? A comparative study. Applied Economics Letters, 16(3), 227-232. DOI: 10.1080/13504850601018320

Macieira, M.H.C. (2009). The determinants of self-employment. Universidade Tecnica de Lisboa.

OECD (2014). Self-employment. W: OECD Factbook 2014: Economic, environmental and social statistics. OECD Publishing.

Özcan, B. (2011). Only the lonely? The influence of the spouse on the transition to selfemployment. Small Business Economics, 37(4), 465-492. DOI: 10.1007/s11187-011-9376-x

Parker, S., Rougier, J. (2007). The retirement behaviour of the self-employed in Britain. Applied Economics, 39(6), 697-713. DOI: 10.1080/000368405004477807

Piróg, D. (2014). Uwarunkowania przedsiębiorczości absolwentów szkół wyższych: założenia teoretyczne i stan rzeczywisty. Przedsiębiorczość - Edukacja, 10, 306-315.

Portes, A., Jensen, L. (1989). The enclave and the entrants: Patterns of ethnic enterprise in Miami before and after Mariel. American Sociological Review, 54, 929-949.

Sena, V., Scott, J., Roper, S. (2012). Gender, borrowing patterns and self-employment: some evidence for England. Small Business Economics, 38(4), 467-480. DOI: 10.1007/s11187-010-9272-9

Simoes, N., Moreira, S.B., Crespo, N. (2013). Individual determinants of self-employment entry - What do we really know? MPRA Paper, 1-44.

Szepelska, A. (2013). Samozatrudnienie jako forma wspierania rozwoju przedsiębiorczości regionów. Ekonomia i Prawo, 12(1), 69-80. DOI: ttp://dx.doi.org/10.12775/EiP.2013.006

Taniguchi, H. (2002). Determinants of women's entry into self-employment. Social Science Quarterly, 83(3), 875-893. DOI: 10.1111/1540-6237.00119

Tyrowicz, J. (2011). What distinguishes entrepreneurs? Evidence on the motives for self-employment. Economic Letters, 112, 226-221. DOI: 10.1016/j.econlet.2011.05.010

Tyrowicz, J., Liberda, B., Smyk, M. (2015). Talented workers as entrepreneurs: a new approach to aspirational self-employment. Working Papers, 18(166).

Wach, K. (2015). Środowisko biznesu rodzinnego jako stymulanta intencji przedsiębiorczych młodzieży akademickiej. Przedsiębiorczość i Zarzadzanie, 16(7), cz. 3, 25-40.

Williams, D. (2012) Gender discrimination and self-employment dynamics in Europe. The Journal of Socio-Economics, 41(2), 153-158. DOI: 10.1016/j.socec.2011.08.029

Wysieńska, K. (red). (2012). Sprzedawać, gotować, budować? Plany i strategie Chińczyków $i$ Wietnamczyków w Polsce. Warszawa: ISP.

Zbierowski, P. (2014). Determinanty intencji przedsiębiorczej studentów - wyniki badań. Horyzonty Wychowania, 13(26), 51-63.

van der Zwan, P., Zuurhout, P., Hessels, J. (2013; 2015, 10 września). Entrepreneurship education and self-employment: the role of perceived barriers. Panteia/EIM bv. Pozyskano z: http://www.ondernemerschap.nl/pdf-ez/H201301.pdf

Danuta Piróg, dr hab., jest adiunktem w Instytucie Geografii Uniwersytetu Pedagogicznego w Krakowie. Jej zainteresowania naukowe dotyczą: roli usług edukacyjnych w przygotowywaniu człowieka do optymalnego funkcjonowania w integrującej się Europie, ze szczególnym uwzględnieniem przestrzeni wielokulturowych; metod badań z zakresu geografii społecznej, głównie innowacji dotyczących metod i technik społecznych badań jakościowych; funkcjonowania człowieka na rynku pracy w zmieniających się warunkach, na przykładzie absolwentów studiów wyższych. Autorka swoje doświadczenie naukowe pogłębiała przez czynny udział oraz kierowanie krajowymi i międzynarodowymi projektami badawczymi. Aktualnie zajmuje się przede wszystkim wielowymiarowymi analizami czynników warunkujących procesy tranzycji absolwentów szkół wyższych na rynek pracy oraz nowoczesnymi strategiami diagnozy predyspozycji zawodowych.

Danuta Piróg, PhD, an associated professor at the Pedagogical University of Cracow (Institute of Geography). Her research interests are concerning the following three core areas: the role of educational services in preparing people to function, in the best possible way, in integrating Europe, with particular 
consideration to multicultural settings; social geography research methods, particularly innovations in methods and techniques of social qualitative research; people's functioning on the labour market in evolving circumstances, using the example of higher education graduates. She has been a member of various scientific projects on national and European level. Currently her scientific surveys are devoted to multidimensional analysis of determinants of $\mathrm{HE}$ graduates transition into the labour market and an innovative strategies of vocational counselling.

\section{Adres/Address:}

Uniwersytet Pedagogiczny im. Komisji Edukacji Narodowej w Krakowie

Instytut Geografii

Zakład Dydaktyki Geografii

ul. Podchorążych 2

30-084 Kraków, Polska

e-mail: dbutryn@up.krakow.pl 